\title{
Correction to: Trifluridine/Tipiracil: A Review in Metastatic Gastric Cancer
}

\author{
Connie Kang ${ }^{1} \cdot$ Sohita Dhillon ${ }^{1} \cdot$ Emma D. Deeks $^{1}$
}

Published online: 18 September 2019

(c) Springer Nature 2019

\section{Correction to: Drugs 2019 79:1583-1590 https://doi.org/10.1007/s40265-019-01195-w}

The article Trifluridine/Tipiracil: A Review in Metastatic Gastric Cancer, written by Connie Kang, Sohita Dhillon and Emma D. Deeks, was originally published Online First without open access. After publication in volume 79, issue 14, pages 1583-1590 Servier Affaires Médicales Oncologie, requested that the article be Open Choice to make the article an open access publication. Post-publication open access was funded by Servier Affaires Médicales Oncologie. The article is forthwith distributed under the terms of the Creative Commons Attribution-NonCommercial 4.0 International License (http://creativecommons.org/licen ses/by-nc/4.0/), which permits any noncommercial use, duplication, adaptation, distribution and reproduction in any medium or format, as long as you give appropriate credit to the original author(s) and the source, provide a link to the Creative Commons license and indicate if changes were made.

The original article has been corrected.

Open Access This article is distributed under the terms of the Creative Commons Attribution-NonCommercial 4.0 International License (http://creativecommons.org/licenses/by-nc/4.0/), which permits any noncommercial use, distribution, and reproduction in any medium, provided you give appropriate credit to the original author(s) and the source, provide a link to the Creative Commons license, and indicate if changes were made.
The original article can be found online at https://doi.org/10.1007/ s40265-019-01195-w.

Connie Kang

demail@ springer.com

1 Springer Nature, Private Bag 65901, Mairangi Bay, Auckland 0754, New Zealand 